\title{
KOMUNIKASI KELUARGA PESANTREN DALAM PEMBELAJARAN POLITIK (Studi Etnografi terhadap Keluarga Pembina Pondok Pesantren Assyakirriy di Kabupaten Jember - Jawa Timur)
}

Oleh:

Ihwan Huda Al Mujib, Anang Sudjoko, dan Antoni

Prodi S2 Ilmu Komunikasi, Fakultas Ilmu Sosial dan Politik, Universitas Brawijaya

E-mail : almujibassyakirriy@gmail.com, anangsudjoko@ub.ac.id, ant_ui@yahoo.com

\begin{abstract}
Abstrak
Komunikasi keluarga terkait pendidikan merupakan suatu hal yang sangat penting dalam keluarga pesantren. Kyai memberikan pembelajaran politik kepada anggota keluarga untuk mempertahankan pengaruhnya yang sangat besar di masyarakat. Terlebih keluarga pesantren memiliki keunikan yaitu tidak akan memilih orang lain untuk meneruskan perjuangan kyai. Namun beberapa ahli menyatakan bahwa peran komunikasi keluarga terkait politik masih sangat kurang. Tujuan penelitian ini adalah untuk mengetahui bentuk komunikasi keluarga pesantren dalam pembelajaran politik. Penelitian ini menggunakan pendekatan kualitatif studi etnografi untuk mengungkapkan realitas komunikasi keluarga pesantren terkait pembelajaran politik. Hasil penelitian menunjukkan pembelajaran politik dalam keluarga pesantren dilakukan dengan beberapa cara yaitu Jagongan politik, menyampaikan pesan pembelajaran politik melalui Umy, menyampaikan pembelajaran politik melalui telephone selular, dan mendampingi komunikasi politik kyai dengan actor politik dan pejabat negara. Maтрu memahami materi pembelajaran politik dan melaksanakannya dalam kegiatan politik merupakan wujud tercapainya koordinasi pembelajaran politik di keluarga pesantren.
\end{abstract}

Kata Kunci : Komunikasi Keluarga, Keluarga Pesantren, Pembelajaran Politik.

\begin{abstract}
Family communication related education is a very important thing in the family of pesantren. Kyai (Saint of Islam) giving political education for family members to maintains a very large influence of society. Moreover, pesantren family has a uniqueness, they will not choose other people to continue the kyai struggle. However, some experts claim that politics related to family communication is still lacking. The purpose of this research is to know the form of communication communication of pesantren family in political learning. The study used a qualitative approach of ethnographic studies to reveal the reality communication of pesantren family related to political learning. The result of the research shows that political learning in pesantren family is done in several ways, such as political jagongan, delivering political learning message through Umy (Mother), delivering political learning through cellular telephone, an accompanying political communication of kyai with politician and goverments. Being able to understand learning materials and implement them in political activities is a form of achieving coordination of political learning in pesantren families.
\end{abstract}

Keywords : Familly Communication, Pesantren Families, Political learning.

\section{A. PENDAHULUAN}

Keluarga pesantren adalah keturunan kyai yang tinggal di lingkungan pesantren dan terlibat secara aktif dalam kegiatan pesantren (Sumbullah \& Hidayati, 2009). Keluarga pesantren memiliki sebuah keunikan, kyai sebagai pemimpin keluarga tidak akan pernah memilih seseorang dari luar keluarganya terkait dengan penerus perjuanganya selama ini 
(Sidqi, 2008). Hal ini diperkuat dengan jalinan yang solid dan tertutup antar kerabat dalam pesantren bagi masyarakat awam dan pernikahan endogamous atau kerabat dekat dalam keluarga pesantren (Dhofier, 2015; Geertz, 1983: 176).

Komunikasi keluarga juga dinilai sangat penting dalam keluarga pesantren, terutama dalam hal pendidikan untuk meneruskan perjuangan dan menjaga pengaruh kyai di tengah masyarakat (Dhofier, 2015). Ajaran Islam yang disampaikan kyai kepada para putranya merupakan salah satu kunci yang sangat utama dalam menjadikan generasi yang sholeh dan sukses (Benharoon, 2013). Pembelajaran yang diberikan oleh kyai dalam keluarga merupakan salah satu cara kyai untuk mempertahankan pengaruhnya yang sangat besar sebagai tokoh masyarakat.

Kyai sebagai pemimpin dalam keluarga pesantren mempunyai kewajiban untuk mengajarkan pendidikan agama kepada para anggota keluarga (Sunarto, 1992). Kyai menganggap bahwa keluarga merupakan suatu lembaga yang sangat penting dalam mempersiapkan generasi penerus perjuangan dan mempertahankan pengaruhnya dalam masyarakat (Dhofier, 2015). Hal ini senada dengan Khani, Fard, \& Boroomand (2015) yang menyatakan bahwa keluarga sangat berpengaruh dalam bidang pendidikan. Bidang pendidikan politik, keluarga memainkan peran penting terhadap pengalaman dan persepsi anak tentang politik (Esau \& Roman, 2015). Disisi lain, Leddbetter (2015) mengungkapkan bahwa peran komunikasi keluarga dalam bidang politik masih belum maksimal.

Selain itu, penelitian komunikasi keluarga masih sangat sedikit (Berger, Roloff, \& Ewoldson, 2015; 687). Hal ini sangat bertolak belakang dengan pernyataan beberapa peneliti yang menganggap bahwa komunikasi keluarga sangat penting (Hirabayashi, 2009). Odenweller, Rittenour, Myers, \& Brann (2011) juga menjelaskan alasan mengenai pentingnya komunikasi keluarga. Pertama, komunikasi dengan anggota keluarga merupakan komunikasi pertama yang dilakukan dan merupakan saluran awal bagi anak anak dalam mempelajari nilai dan norma dalam keluarga maupun masyarakat. Kedua, keluarga mencirikan suatu karakteristik unik tentang ideology, nilai - nilai, dan sistem keyakinan yang menegaskan anggota sosial. Ketiga, baik sengaja maupun tidak anggota keluarga saling berkomunikasi dan mengadopsi gaya komunikasi, nilai - nilai, ideology, dan perilaku yang diharapkan diterima dalam masyarakat.

Dari deskripsi diatas, peneliti membuat simpulan. Perlu dilakukan penelitian terkait komunikasi keluarga pesantren terkait pembelajaran politik. Berdasarkan kesimpulan tersebut, peneliti memunculkan keingintahuan. Bagaimana komunikasi keluarga pesantren terkait proses pembelajaran politik?

\section{B. TINJAUAN PUSTAKA}

\section{Keluarga Pesantren}

Keluarga pesantren merupakan keluarga yang berasal dari keturunan kyai, mempunyai dan mengelola pesantren, dan tinggal dalam lingkungan pesantren (Sumbulah \& Hidayati, 2009). Pesantren dalam hal ini merupakan lembaga pendidikan yang mempunyai beberapa elemen seperti mushola, pondok, pembelajaran kitab kuning, dan kyai (Dhofier, 2015). Geertz (1983: 172) 
menjelaskan santri sebagai kelompok urban yang melaksanakan tuntunan ajaran Islam dalam segala aspek moral dan sosialnya.

Kyai menerapkan system "dinasti" dalam hal meneruskan perjuanganya, penerusnya nanti tidak berasal dari luar kalangan pesantren tersebut (Sidqi, 2008). Hal ini diperkuat dengan jalinan yang kuat dan tertutup antar kerabat dalam pesantren bagi masyarakat awam (Dhofier, 2015). Selain itu, keluarga pesantren mempunyai karakteristik yang unik dibanding dengan keluarga pada umumnya. Dhofier (2015) kemudian menjelaskan keunikan tersebut. Pertama, dalam keluarga pesantren kerabat terdekat harus menjadi calon pengganti yang kuat untuk meneruskan kepemimpinan dan hal ini selalu dilestarikan. Kedua, melestarikan sistem pernikahan antar keluarga dekat. Ketiga, mengembangkan intelektual chains sesama keluarga kyai dan saudara terdekatnya.

\section{Komunikasi Keluarga}

Keluarga, merupakan tempat pertama seseorang dalam melakukan komunikasi (Odenweller, Rittenour, Myers \& Brann, 2011). Keluarga merupakan sebuah sistem sosial yang setiap anggota mempunyai tugas dan fungsi masing masing (Ledbetter, 2015). Orangtua dan anak memiliki arti yang sangat penting untuk saling memantau kondisi dan perkembangan masing - masing dengan melakukan proses komunikasi. komunikasi orangtua dalam keluarga adalah proses menyampaikan informasi, norma, atau aturan keluarga, mempersuasi anggota keluarga untuk melakukan pekerjaan tertentu dan untuk menyatukan anggota keluarga dalam satu lembaga keluarga yang harmonis.

Seseorang tidak dapat menolak pentingnya komunikasi keluarga dalam kehidupan sehari - hari (Benharoon, 2013). Komunikasi antar anggota keluarga selalu menjadi pertimbangan dan menjadi aspek utama dalam hubungan interpersonal (Zarnaghash, Zarnaghash, \& Zarnaghash, 2013). Koerner \& Fitzpatrick dalam Soltani dkk (2013) menyatakan bahwa komunikasi antar anggota keluarga memainkan peran penting dalam pengembangan kemampuan untuk mempertahankan kesuksesan hubungan interpersonal.

\section{Teori Coordinated Management of Meanings}

Teori ini mampu menjelaskan beberapa aspek dan menganalisis semua kegiatan manusia dalam terminologi perspektif komunikasi (Littlejohn \& Foss, 2009: 255). Cronen, Pearce, \& Harris dalam Orbe \& Camara (2010) menyatakan bahwa CMM menjelaskan secara mendasar bagaimana seseorang menciptakan, memelihara, dan mengubah tata cara sosial, hubungan personal, indentitas individu. Teori CMM diharapkan mampu untuk menjelaskan secara mendasar bagaimana kyai menciptakan, memelihara, dan mengubah perilaku social politik anggota keluarga, hubungan personal, identitas anggota keluarga pesantren melalui pembelajaran politik.

Untuk memahami coordinated management of meanings (CMM) lebih dalam, Littlejhon \& Foss (2009: 255-262) menjelaskan tiga kunci dalam teori CMM. Tiga kunci tersebut adalah : 
1. Makna dan Tindakan

Setiap pelaku komunikasi menginterpretasikan dan melakukan tindakan berdasarkan pengalaman mereka, dan pengalaman tersebut merupakan konteks yang telah terbentuk berdasarkan makna dan tindakan dengan situasi (Littlejohn \& Foss, 2009: 256).

Makna dan tindakan dikonstruksikan dari dua aturan, yaitu constructive rules dan regulative rules (Littlejohn, \& Foss, 2009: 257). Constructive rules merupakan garis pedoman yang mengungkapkan, membantu menjawab pertanyaan yang sangat mendasar (Swords dkk., 2014). Regulative rules merupakan cara yang digunakan untuk menetapkan bagaimana cara menyikapi dan bertindak (Littlejohn \&Foss, 2009: 257). Regulative Rules kemudian dibagi kembali menjadi empat jenis kekuatan logika yaitu kausal, praktis, kontekstual, dan implicative. Kemudian kekuatan logika tersebut dipengaruhi oleh logika deontic yang dibagi secara sadar maupun tidak sadar. Kategori sadar terdiri dari Obligatory (kewajiban), Legitimate (hal-hal yang resmi), Prohibited (hal-hal yang dilarang), dan Undetermined (hal-hal yang tidak dapat ditentukan). Kategori kedua mendefinisikan pilihan secara tidak sadar (Unconscious Choice) seperti hal-hal yang tidak disengaja (Random), hal-hal yang terhalang (Blocked), hal-hal yang menyebabkan terjadinya sesuatu (Caused) dan hal-hal yang belum pasti (Probable) (Pawanteh, 1996: $85)$.

2. Koordinasi

Koordinasi melibatkan pengaturan tindakan antarpribadi, sehingga pelaku komunikasi merasa melakukan sebuah cara yang tepat dan rasional (Littlejohn \& Foss, 2009: 260). Terdapat tiga hasil yang akan diperoleh dari koordinasi tersebut menurut West \& Turner (2013). Pertama, tercapainya koordinasi. Kedua, tidak tercapainya koordinasi. Ketiga, tercapainya koordinasi pada tingkat tertentu.

3. Kisah

Terdapat enam komponan kisah yang disampaikan oleh Littlejohn \& Foss (2009: 261). Enam komponan kisah tersebut adalah Storie Lived (pengalaman hidup), Untold Storie (cerita yang tidak dibagikan), Unheard storie (cerita yang disampaikan namun yang menerima tidak memahami), Unknown storie (cerita yang sudah menjadi konsumsi publik namun tidak diketahui oleh komunikator), Storie told (cerita-cerita atau narasi yang kita gunakan untuk memaknai perbuatan yang dianggap rasional dan tepat), dan Storie telling (realitas sosial kita diciptakan berdasarkan aturan dari makna, tindakan dan konteks).

\section{METODE PENELITIAN}

Penelitian ini menggunakan metode penelitian kualitatif studi etnografi komunikasi. Penelitian kualitatif mempunyai tujuan untuk menggambarkan data hasil penelitian dengan sangat detail melalui pengumpulan data yang sangat mendalam 
(Kriyantono, 2007: 67). Pendekatan studi etnografi komunikasi dipilih oleh peneliti bertujuan untuk mengungkapkan secara mendalam berbagai aspek budaya, pengalaman hidup, kepercayaan, sistem nilai dari keluarga pesantren. Informan dalam penelitian ini adalah keluarga K.H Mohan Assyakirriy yang merupakan pembina pondok pesantren Assyakirriy di Jember Jawa Timur. Teknik pemilihan informan dalam penelitian ini menggunakan teknik purposive sampling. Teknik ini memilih informan berdasarkan kriteria tertentu yang telah ditetapkan untuk mendapatkan tujuan penelitian (Kriyantono, 2007: 158). Sedangkan teknik pengumpulan data penelitian ini didapatkan dari transkrip hasil wawancara secara mendalam, observasi partisipan, dan dokumentasi. Lokasi penelitian dilakukan di Kabupaten Jember Jawa Timur.

\section{PEMBAHASAN}

Berikut ini beberapa cara yang dilakukan oleh K.H Mohan Assyakirriy dalam memberikan pembelajaran politik kepada anggota keluarga:

\section{Jagongan Politik}

Jagongan politik merupakan cara pertama yang dilakukan oleh K.H Mohan Assyakirriy dalam memberikan pembelajaran politik. Salah satu Jagongan politik yang pernah peneliti ikuti dalam observasi partisipan adalah membahas tentang jabatan politik. K.H Mohan Assyakirriy memberikan materi tentang jabatan politik saat itu dikarenakan rencana salah satu anggota keluarga yang meminta ijin untuk maju sebagai anggota DPR RI pada pemilu 2019. K.H Mohan Assyakirriy menyampaikan sebuah hadist Nabi Muhammad yang ada dalam kitab Riyadhus Shalihin yang berisi tentang larangan memberikan jabatan politik kepada orang yang ingin menjadi pejabat negara.

Jagongan politik yang dilaksanakan saat itu merupakan Regulaitve Rules yang dipengaruhi oleh kekuatan kausal. K.H Mohan Assyakirriy melaksanakan Jagongan politik dikarenakan Putra Kedua sebelumnya meminta ijin untuk mencalonkan diri menjadi anggota DPR RI 2019. Kisah yang disampaikan oleh K.H Mohan Assyakirriy merupakan Stories Lived atau pengalaman hidup seseorang (Littlejohn \& Foss, 2009, h. 203).

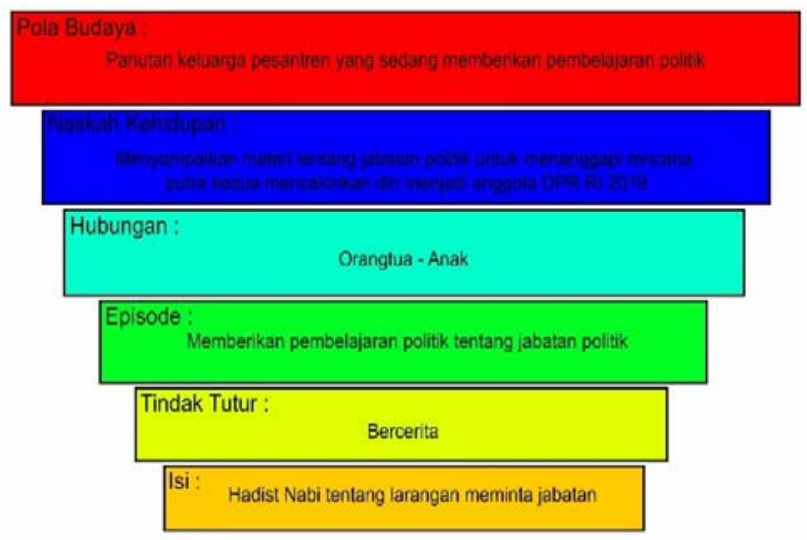

Gambar 1. Hierarki makna K.H Mohan Assyakirriy episode jagongan politik materi larangan meminta jabatan politik 


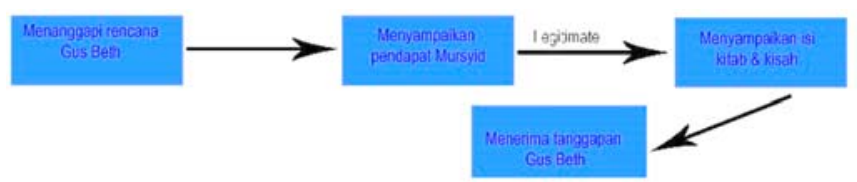

Gambar 2. Urutan tindakan K.H Mohan Assyakirriy episode jagongan politik materi larangan meminta jabatan politik

Putra Kedua menyatakan akan mengurungkan niatnya untuk mencalonkan diri menjadi anggota DPR RI 2019. Tindakan Putra Kedua mengurungkan niatnya untuk mencalonkan diri menjadi anggota DPR RI 2019 merupakan Regulative Rules yang dipengaruhi oleh kekuatan kausal dan logika deontik prohibited. Logika deontik prohibited merupakan sebuah tindakan yang disadari oleh seseorang untuk menghindari hal hal yang terlarang (Pawanteh, 1996).

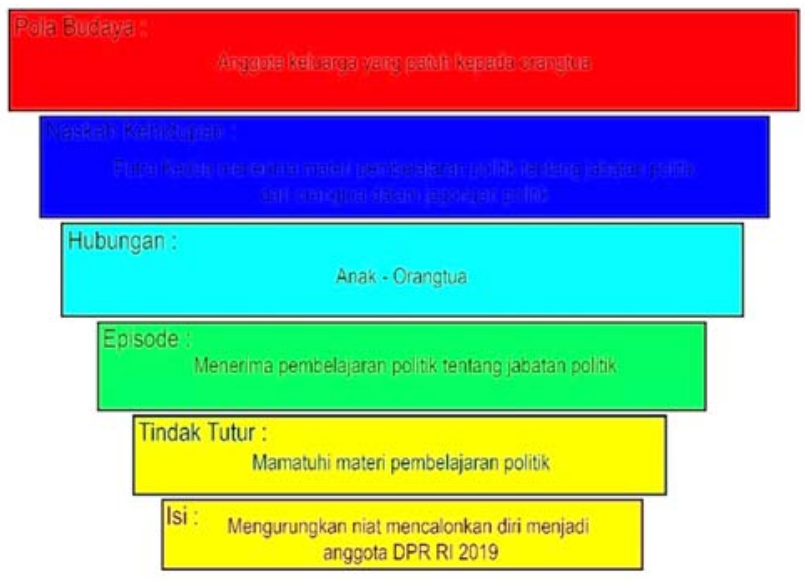

Gambar 3. Hierarki makna Putra Kedua episode menerima materi tentang jabatan politik

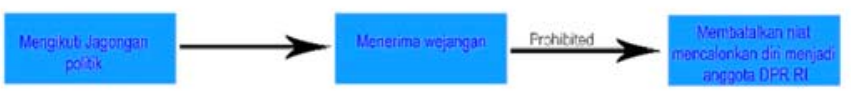

Gambar 4. Urutan Tindakan Putra Kedua episode menerima materi tentang jabatan politik

Koordinasi dapat tercapai dapat Jagongan politik yang dilakukan oleh K.H Mohan Assyakirriy. Tercapainya koordinasi dalam Jagongan politik ini nampak pada anggota keluarga yang memahami materi pembelajaran politik yang diberikan dan melaksanakannya dalam kegiatan politik.

\section{Menyampaikan Pesan Pembelajaran Politik melalui Umy}

Waktu Gus Nur selama masa Uzlah sangat terbatas. Oleh karena itu, untuk mengatasi hambatan waktu yang sangat terbatas dalam berkomunikasi dengan anggota keluarga, K.H Mohan Assyakirriy menyampaikan pesan pembelajaran 
politik melalui Umy atau istrinya untuk kemudian disampaikan kembali kepada anggota keluarga.

Selama observasi partisipan, Peneliti beberapa kali mengetahui Umy menyampaikan pesan pembelajaran politik kepada anggota keluarga. K.H Mohan Assyakirriy menyampaikan pesan melalui Umy tentang larangan untuk berambisi menjadi pimpinan dalam kegiatan politik.

Tindakan K.H Mohan Assyakirriy menyampaikan pesan melalui Umy merupakan Regulative Rules yang dipengaruhi oleh kekuatan konstekstual. K.H Mohan Assyakirriy mempunyai waktu yang sangat terbatas untuk menyampaikan pesan tersebut kepada anggota keluarga. Sedangkan tindakan Umy menyampaikan pesan dari K.H Mohan Assyakirriy kepada anggota keluarga merupakan Regulative Rules yang dipengaruhi oleh kekuatan kausal yang mengarah pada logika deontik obligatory. Suatu kewajiban bagi seorang istri untuk menyampaikan pesan yang telah diperintahkan oleh suami.

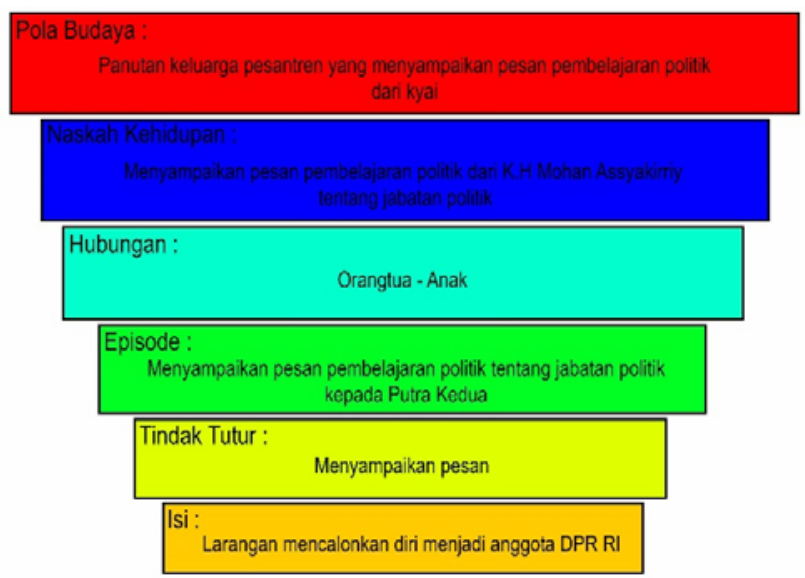

Gambar 5. Hierarki makna Umy episode menyampaikan pesan tentang jabatan politik

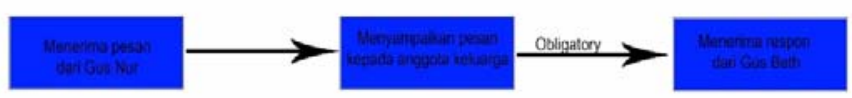

Gambar 6. Urutan tindakan Umy episode menyampaikan pesan tentang jabatan politik

Putra Kedua saat itu langsung memberikan respon mengenai pesan yang disampaikan oleh Umy. Putra Kedua menyatakan akan mengurungkan niat mencalonkan diri menjadi anggota DPR RI 2019. Tindakan tersebut merupakan Regulative Rules yang dipengaruhi oleh kekuatan kausal dan mengarah pada logika deontik prohibited. 


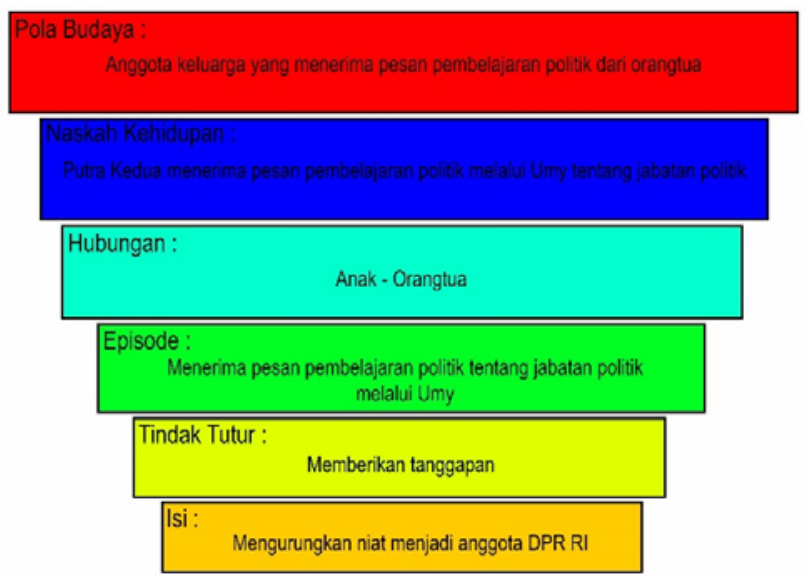

Gambar 7. Hierarki makna Putra Kedua episode menerima pesan tentang jabatan politik

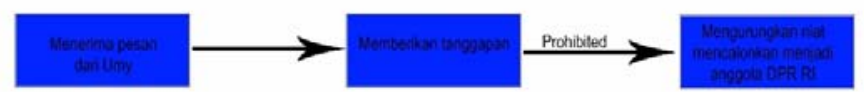

Gambar 8. Urutan tindakan Putra Kedua episode menerima pesan tentang jabatan politik

Koordinasi dapat tercapai dalam menyampaikan pesan pembelajaran politik melalui Umy. Tercapainya koordinasi ini nampak pada anggota keluarga yang memahami materi pembelajaran politik yang diberikan dan melaksanakannya dalam kegiatan politik.

\section{Menyampaikan Pembelajaran Politik melalui Telephone Selular}

Waktu merupakan hambatan bagi K.H Mohan Assyakirriy dalam berkomunikasi dengan anggota keluarga. Menyampaikan pesan pembelajaran politik melalui Umy merupakan cara pertama yang dilakukan oleh Gus Nur untuk mengatasi hambatan tersebut. Cara kedua adalah menyampaikan pembelajaran politik melalui telephone selular.

K.H Mohan Assyakirriy juga pernah menghubungi Putra Pertama melalui telephone selular dan memberikan materi pembelajaran politik. Pesan yang disampaikan K.H Mohan Assyakirriy berupa instruksi untuk tidak mencari perhatian di depan umum ketika melakukan kegiatan politik. K.H Mohan Assyakirriy kemudian menceritakan kisah pribadinya dengan salah satu jamaah majelis dzikir.

Tindakan K.H Mohan Assyakirriy menyampaikan pesan melalui telephone selular merupakan Regulative Rules yang dipengaruhi oleh kekuatan praktis. Dalam hal ini tindakan tersebut dilakukan untuk mencapai tujuan tertentu dimasa depan yaitu agar Putra Pertama melakukan kegiatan politik dengan baik dengan tidak mencari perhatian dan ingin tampil di depan. Sedangkan tindakan K.H Mohan Assyakirriy menyampaikan kisah pengalaman hidupnya merupakan Regulative Rules yang dipengaruhi oleh kekuatan kontekstual. K.H Mohan Assyakirriy 
meyakini bahwa kisah yang disampaikan mengenai salah satu jamaahnya tersebut merupakan suatu hal yang natural dan merupakan bagian daripada konteks.

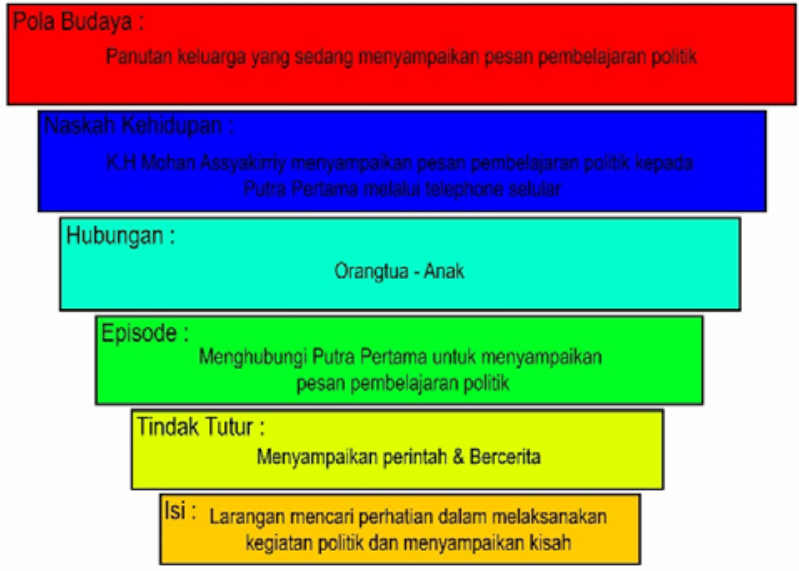

Gambar 9. Hierarki makna K.H Mohan Assyakirriy episode menghubungi Putra Pertama menyampaikan pesan pembelajaran politik

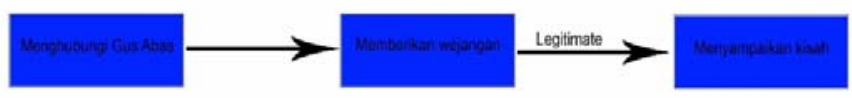

Gambar 10. Urutan tindakan K.H Mohan Assyakirriy episode menghubungi Putra Pertama menyampaikan pesan pembelajaran politik

Tindakan Putra Pertama merupakan Regulative Rules yang dipengaruhi oleh kekuatan kausal dan mengarah pada logika deontik obligatory. Putra Pertama melakukan tindakan yang diperintahkan oleh Gus Nur dan kewajiban sebagai anggota keluarga mematuhi perintah K.H Mohan Assyakirriy.

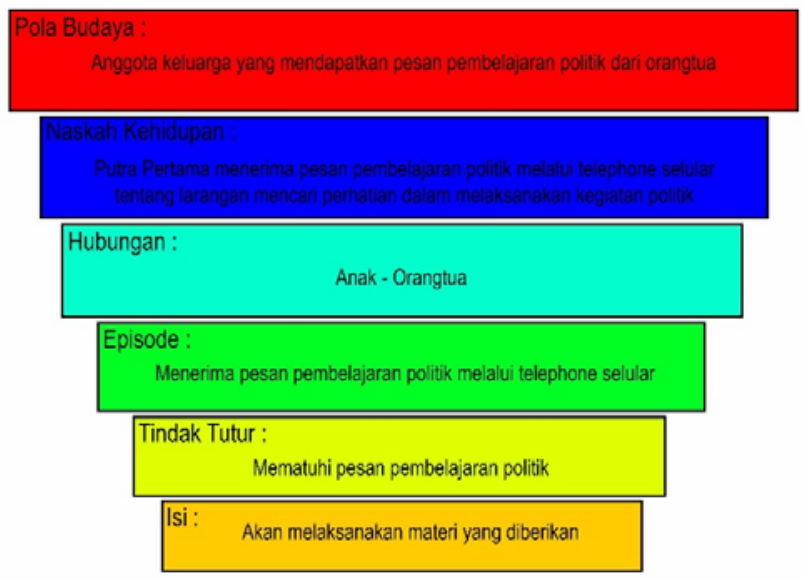

Gambar 11. Hierarki makna Putra Pertama episode menerima pembelajaran politik melalui telephone selular 


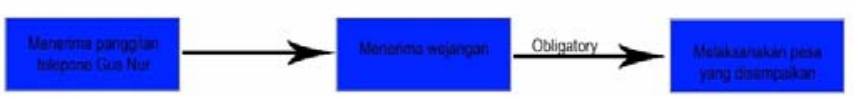

Gambar 12. Urutan tindakan Putra Pertama episode menerima pembelajaran politik melalui telephone selular

Tercapainya koordinasi dalam menyampaikan pesan pembelajaran politik melalui telephone selular ini nampak pada anggota keluarga yang memahami materi pembelajaran politik yang diberikan dan melaksanakannya dalam kegiatan politik.

\section{Mendampingi Kyai dalam Komunikai Politik dengan Aktor Politik dan Pejabat} Negara

Kedua putra K.H Mohan Assyakirriy yang aktif dalam dunia politik selalu ikut mendampingi dalam melakukan komunikasi politik. Kedua anggota keluarga tersebut mendapatkan pembelajaran politik selama mendampingi komunikasi politik K.H Mohan Assyakirriy. Kedua anggota keluarga tersebut menyatakan bahwa pembelajaran politik yang didapatkan adalah mengenai komunikasi politik. Yaitu tentang bagaimana kita bisa berkomunikasi politik dengan baik, santun, efektif, dan meninggalkan kesan kepada actor politik dan pejabat negara.

Tindakan K.H Mohan Assyakirriy mengutus anggota keluarga untuk mendampingi dalam komunikasi politik merupakan Regulative Rules yang dipengaruhi oleh kekuatan praktis. K.H Mohan Assyakirriy mempunyai tujuan yaitu memberikan pembelajaran politik secara langsung dan Uswah kepada anggota keluarga ketika melaksanakan komunikasi politik.

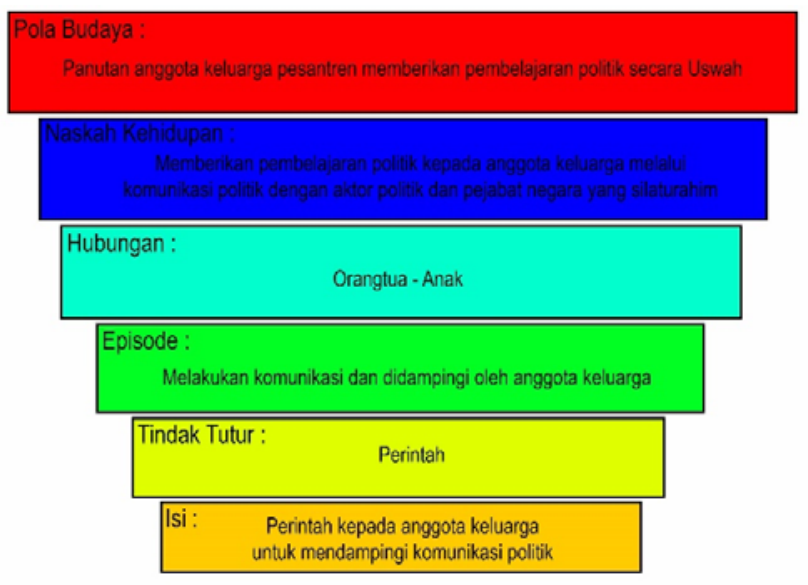

Gambar 13. Hierarki makna K.H Mohan Assyakirriy episode melakukan komunikasi politik dan didampingi angota keluarga

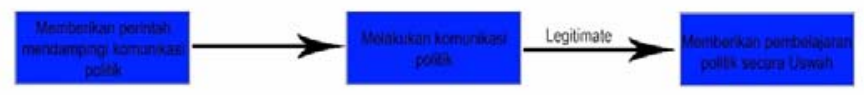

Gambar 14. Urutan tindakan K.H Mohan Assyakirriy episode melakukan komunikasi politik dan didampingi angota keluarga 
Anggota keluarga selalu mendampingi K.H Mohan Assyakirriy dalam melaksanakan komunikasi politik. Tindakan anggota keluarga tersebut merupakan Regulative Rules yang dipengaruhi oleh kekuatan kausal dan mengarah pada logika deontik obligatory. Tindakan yang dilakukan Karena suatu hal sebelumnya dan merupakan sebuah kewajiban untuk melakukannya.

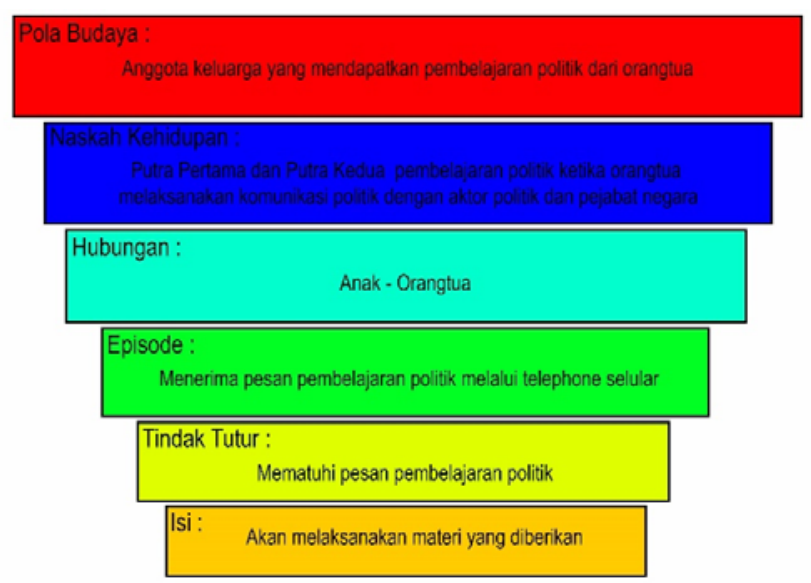

Gambar 15. Hierarki makna anggota keluarga episode mendampingi komunikasi politik kyai

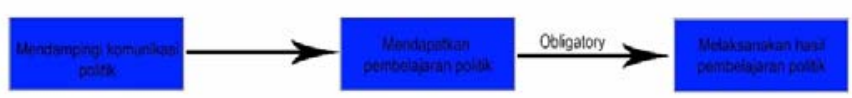

Gambar 16. Urutan tindakan anggota keluarga episode mendampingi komunikasi politik kyai

Tercapainya koordinasi dalam menyampaikan pesan pembelajaran politik melalui telephone selular ini nampak pada anggota keluarga yang memahami materi pembelajaran politik yang diberikan dan melaksanakannya dalam kegiatan politik.

\section{E. SIMPULAN}

Berdasarkan hasil penelitian tentang komunikasi keluarga pesantren terkait pembelajaran politik, peneliti mendapatkan beberapa kesimpulan sebagai berikut:

1. Percakapan sangat mendominasi pembelajaran politik dalam keluarga pesantren.

2. Kisah mempunyai peranan penting sebagai materi pembelajaran politik dalam keluarga pesantren.

3. Kyai sebagai pemimpin keluarga pesantren membutuhkan peranan istri dalam menyampaikan pesan pembelajaran politik.

4. Memahami materi yang disampaikan dan melaksanakannya dalam kegiatan politik merupakan wujud tercapainya koordinasi dalam keluarga pesantren terkait pembelajaran politik. 


\section{DAFTAR PUSTAKA}

Benharoon, S. Y. (2013). Building a Culture of peace in Muslim Community in Southern Thailand Through FamilyCommunication. Procedia - Social and Behavioral Sciences. 91, 522-531.

Berger, C. R., Roloff, M. E., \& Ewoldsen, D. R. R. (2015). Handbook Ilmu Komunikasi. BANDUNG. Nusa Media.

Dhofier, Z. (2011). Tradisi Pesantren. Jakarta: LP3ES.

Esau, M. V. \& Roman, N. V. (2015). Political Socialization of the Youth: An Examination of the Family as an Agency for Youth Citizenship in South Africa. Nova Science Publisher. 1-18.

Geertz, C. (1983). Abangan, Santri, Priyayi, Jakarta: Pustaka Jaya.

Hirabayashi, N. (2009). Family Communication Patterns and Young Adults Relational Maintenance in Parent-Child Relationships in Japan and Thailand (Doctoral dissertation, HAWAII PACIFIC UNIVERSITY). Proquest Publisher.

Khani, F., Fard, M. S., \& Boroomand, R. (2015). A Study on the Role of Family Communication Patterns on Slow Learners' Academic Achievement in the City of Bandar Abbas. Academic Journal of Psychological Studies, 4(3).

Kriyantono, R. (2007). Teknik Praktis Riset Komunikasi. Jakarta: Kencana Prenada Media.

Ledbetter, A. M. (2015). Political Philosophy as a (Partial) Mediator of the Association between Family Communication Patterns and Perception of Candidate Credibility in the 2012 US Presidential Election. Journal of Family Communication, 15(3), 214-231.

Littlejohn, S. W \& Foss, K. A. (2009). Teori Komunikasi Edisi 9. Jakarta. Salemba Humanika.

Odenweller, K. G., Rittenour, C. E., Myers, S. A., \& Brann, M. (2011). Father-Son Family Communication Patterns and Gender Ideologies: A Modeling and Compensation Analysis. Journal of FamilyCommunication, 13(4), 340-357.

Orbe, M. P. \& Camara, S. K. (2010). Defining Discrimination across Cultural Groups: Exploring The [un-] Coordinated Management of Meaning. Elsevier. 34, 283-293.

Pawanteh, Latiffah. (1996). Stories of Sojourn: A CMM Analysis of the Intercultural Interaction of Malay Women. Massachusetts, University of Massachusetts Amherst. Disertasi.

Pearce, W. B., \& Pearce, K. A. (2000). Extending the Theory of the Coordinated Management of Meaning (CMM) Through a Community Dialogue rocess. International Communication Association: Communication

Sidqi, R. T. (2012). Model Kepemimpinan Dinasti Pesantren: Studi Kepemimpinan Kyai di Pesantren Cipasung Kabupaten Tasikmalaya. Jurnal Unsil. 1-20.

Soltani, A., Hosseini, S., \& Mahmoodi, M. (2013). Predicting Identity Style Based On Family Communication Pattern in Young Males. Procedia-Social and Behavioral Sciences, 84, 1386-1390.

Sunarto, A. (1996). Etika Berumah Tangga, Terj. Syarah Uqudullujain. Surabaya. Al Hidayah.

166 Ihwan Huda Al Mujib, Anang Sudjoko, dan Antoni 
Sumbullah, U., \& Hidayati, E. W. (2009). Keluarga Berencana di Kalangan Keluarga Pesantren Dalam Membentuk Keluarga Sakinah. Egalita.

Swords, N.M., Orbe, M.P., Cooke-Jackson, A., \& Johnson, A.L. (2014). Exploring the Coordinated Management and Meaning of Sex: The Social Construction of Male College Student Logical Forces. Creative Education, 5, 1383-1395.

Zarnaghash, M., Zarnaghash, M., \& Zarnaghash, N. (2013). The Relationship between Family Communication Patterns and Mental Health. Procedia-Social and Behavioral Sciences, 84, 405-410. 


\section{Petunjuk Bagi Penulis}

1. Naskah memperhatikan norma-norma dan etika bahasa serta belum pernah diterbitkan dalam media cetak lain.

2. Artikel yang dimuat dalam jurnal ini meliputi tulisan tentang hasil penelitian, tinjauan pustaka, kajian dan aplikasi teori.

3. Batasan jumlah kata bagi abstrak makalah adalah 150-250 kata. Abstrak tersebut berisi diskripsi singkat, padat, dan jelas tentang makalah yang ditulis, dan menunjukkan keunikan studi/konsep yang dilakukan, disertai dengan kata kunci.

4. Besar huruf untuk judul adalah 16 point, diketik dengan cetak tebal (bold) dan seluruhnya dengan huruf besar. Jumlah kata dalam judul tidak boleh melebihi 10 kata (termasuk sub judul) dan tidak menempati lebih dari tiga baris. Sub Judul diketik dengan cetak tebal (bold) dengan huruf besar pada setiap awal kata, kecuali pada kata sambung). Penulis, keanggotaan penulis dalam institusi pendukung, dan alamat kontak penulis, dan email yang diketik huruf 12 point. Jika penulis didukung memiliki dua institusi pendukung, maka institusi tersebut ditunjukkan dengan angka yang ditulis di belakang nama penulis dengan mode superscript.

5. Badan naskah ditulis menggunakan huruf Times New Roman 11pt, pada kertas Kuarto (A4) margin 4-3, 4-3 cm (atas-kiri-bawah-kanan) dan 1,5 untuk header/footer.

6. Setiap tulisan harus disajikan dengan sistematika sebagai berikut :

Secara garis besar naskah terdiri atas 3 bagian: Pendahuluan, Isi, dan Penutup. Sekaligus berikut ini merupakan pedoman penulisan paragraf bernomor, menggunakan huruf alfabet ( $\mathrm{a}, \mathrm{b}, \mathrm{c}, \mathrm{dst}$.) yang diapit tanda kurung. Isi; bagian ini dapat dibagi dalam beberapa sub pokok pembahasan sesuai dengan kebutuhan tulisan. Tidak ada batasan yang baku mengenai jumlah pemerincian sub pokok bahasannya; tetapi setidaknya mengandung: metode, hasil, dan pembahasan. Penutup, bagian penutup terdiri atas kesimpulan dan daftar acuan.

7. Pengacuan sumber informasi ini dapat berupa: parafrase, ringkasan, atau kutipan. Pengacuan dengan menggunakan frase pengantar terhadap kutipan pendek, parafrase, atau ringkasan; yaitu dengan mencantumkan nama penulis dalam frase pengantar atau menuliskannya dalam tanda kurung tepat setelah frase pengantar dan tanggal publikasi; contoh:

Steve Krug (2006) menyatakan bahwa, "One of the very few welldocumented facts about Web use is that people tend to spend very little time reading most Web pages. Instead, we scan (or skim) them, looking for words or phrases that catch our eye." (pp. 22). 